\title{
PENINGKATAN KEMAMPUAN MENULIS ARTIKEL TENTANG PANDEMI COVID 19 UNTUK PENDIDIKAN KARAKTER SISWA PADA GURU PPKN SMP DI KOTA SURABAYA
}

\author{
Listyaningsih ${ }^{1}$, Totok Suyanto ${ }^{2}$, Oksiana Jatiningsih ${ }^{3}$,Agus Satmoko ${ }^{4}$, Iman Pasu Purba \\ 1,2,3,4,5) Program Studi PPKn, Fakultas Ilmu Sosial \& Hukum, Universitas Negeri Surabaya \\ e-mail: listiyaningsih@unesa.ac.id
}

\begin{abstract}
Abstrak
Kemampuan dalam menulis bagi guru saat ini merupakan suatu keharusan. Guru profesional tidak hanya menguasai kemampuan dalam pembelajaran sesuai dengan bidangnya, tetapi kemampuan dalam hal menulis karya ilmiah ini juga menjadi suatu tuntutan yang harus dilakukan oleh guru. Bagi guru kegiatan menulis dalam bentuk karya ilmiah dirasakan sebagai hal yang sulit, padahal karya ilmiah yang dihasilkan guru ini diperlukan dalam peningkatan karier dan peningkatan pengetahuan bagi guru. Namun fakta menunjukkan, bahwa kemampuan guru untuk menulis (artikel) masih sangat rendah. Kira-kira hanya 20\% yang mau menulis. Alasan guru jarang menulis artikel adalah karena faktor usia, kemampuan untuk menulis artikel rendah dan kesibukan guru dalam hal administratif. Berdasarkan atas fakta tersebut di atas maka PKM ini diarahkan pada upaya meningkatkan kemampuan guru dalam menulis artikel tentang covid 19 dalam rangka pendidikan karakter pada peserta didik SMP kota Surabaya. Dengan melakukan penguatan melalui diskusi dan workshop secara online, kemampuan para Guru yang mengikuti program mengalami peningkatan.
\end{abstract}

Kata kunci: Menulis, Artikel, Covid 19, Pendidikan, Karakter

\begin{abstract}
Today's teacher writing skills are a must. Professional teachers not only master the skills in learning according to their fields, but the ability to write scientific papers is also a requirement that teachers must do. For teachers, writing activities in the form of scientific papers are perceived as difficult, even though scientific work produced by these teachers is needed in career advancement and increasing knowledge for teachers. However, the facts show that the teacher's ability to write (articles) is still very low. Approximately only $20 \%$ are willing to write. The reason the teacher rarely writes articles is due to age, the ability to write low articles and the teacher's busyness in administrative matters. Based on the facts above, this PKM is directed at improving the ability of teachers to write articles about Covid 19 in the context of character education for junior high school students in Surabaya. By doing strengthening through online training, the ability of teachers who participate in the program has increased.
\end{abstract}

Keywords: Writing, Article, Covid 19, Education, Character

\section{PENDAHULUAN}

Kemampuan dalam menulis bagi guru saat ini merupakan suatu keharusan. Guru professional tidak hanya menguasai kemampuan dalam pembelajaran sesuai dengan bidangnya, tetapi kemampuan dalam hal menulis karya ilmiah ini juga menjadi suatu tuntutan yang harus dilakukan oleh guru. Bagi guru kegiatan menulis dalam bentuk karya ilmiah dirasakan sebagai hal yang sulit, padahal karya ilmiah yang dihasilkan guru ini diperlukan dalam peningkatan karier dan peningkatan pengetahuan bagi guru.

Berdasarkan penelitian yang dilakukan oleh Ritnaningsih (2015) ditemukan beberapa alasan mengapa guru tidak menulis karya ilmiah? Alasan utama dan merupakan alasan tertinggi adalah karena kurang atau tidak adanya waktu yang tersedia untuk menulis. Tugas guru yang cukup banyak sebagai guru kelas, mendidik anak didik di sekolah, dan adakalanya memberikan bimbingan bagi anak didik di luar kelas, hal ini sangat menyita waktu. Kedua, guru masih bingung mau menulis apa, kurang ide untuk memulai menulis, sulit mencari ide. Ketiga, adalah adanya rasa 
malas untuk menulis. Keempat, kurang memiliki kemauan (motivasi) untuk menulis. Kelima, kurang memahami ilmu menulis yaitu belum paham cara menulis karya tulis ilmiah. Keenam, guru mengakui masih minimnya literature yang dapat dijadikan referensi menulis. Itulah 6 hal utama yang menjadi kendala guru dalam menulis karya ilmiah.

Salah satu bentuk karya ilmiah yang bisa dibuat oleh guru adalah artikel. Artikel adalah fakta yang dianalisis sehingga memunculkan pendapat/pandangan penulis atas fakta tersebut. Opini yang disampaikan penulis tentang masalah actual yang menyita perhatian masyarakat. Artikel berisi gagasan yang bertujuan memberitahu, memengaruhi, meyakinkan dan menghibur (Hakim, 2012). Asep Syamsul M. Romli menjelaskan artikel sebagai sebuah karangan faktual (non fiksi), tentang suatu masalah secara lengkap, yang panjangnya tidak ditentukan, untuk dimuat disurat kabar, majalah, bulletin dan sebagainya, dengan tujuan untuk menyampaikan gagasan dan fakta guna meyakinkan, mendidik, menawarkan pemecahan suatu masalah, atau menghibur. Artikel termasuk tulisan ketegori views (pandangan), yaitu tulisan yang berisi pandangan, ide, opini, penilaian penulisnya tentang suatu masalah atau peristiwa (Komara dan Subarkah, 2004).

Berdasarkan beberapa pendapat di atas, dapat disimpulkan bahwa artikel merupakan tulisan yang didasarkan pada fakta, pemikiran, dan pandangan seseorang terhadap suatu peristiwa atau masalah. Dalam menulis artikel pada umumnya diawali dengan menunjukkan data yang merupakan sebuah fakta terhadap suatu peristiwa. Berdasarkan data yang ada itulah penulis bisa memberikan pendapat, pandangan, gagasan, atau bahkan interpretasi dari fakta yang ada pada data tersebut.

Pada masa sekarang ini bangsa Indonesia tengah menghadapi permasalahan Coronavirus Desease (COVID 19). Covid 19 yang mulai muncul pertama kali di Wuhan pada Desember 2019, saat ini menjadi masalah global yang dihadapi oleh seluruh bangsa di dunia termasuk di Indonesia. Covid 19 ini menimbulkan dampak dalam berbagai aspek kehidupan, di bidang kesehatan, sosial, pendidikan, politik, hukum dan lain-lain. Adanya permasalahan-permasalahan tersebut mendorong kita untuk mencari berbagai solusi dalam mengatasi masalah itu.

Dengan adanya kemajuan di bidang teknologi informasi seperti sekarang ini, kesempatan untuk menulis artikel semakin terbuka lebar melalui berbagai media yang ada. Apalagi di tengah pandemic covid sekarang ini kesempatan untuk berkarya membuat tulisan tentang topic covid yang ditinjau dari berbagai aspek dapat dilakukan. Bagi guru, dengan menulis artikel bisa menuangkan gagasan yang bertujuan memberitahu, memengaruhi, meyakinkan pada peserta didik terkait pemberian pengetahuan, bagaimana cara bersikap dan berperilaku yang baik ditengah pandemic Covid 19. Artikel yang dibuat guru ini sekaligus dapat digunakan sebagai sumber belajar (bahan ajar) dalam pembelajaran PPKn. Ada beberapa Kompetensi Dasar (KD) yang relevan yang bisa menggunakan tema covid 19 sebagai bahan pengayaan untuk peserta didik, misalnya pada kelas VII, misalnya 3.5 Menganalisis bentuk-bentuk kerjasama dalam berbagai bidang kehidupan di masyarakat; 4.5 Menunjukkan bentuk-bentuk kerjasama di pelbagai bidang kehidupan masyarakat; atau kelas IX pada KD 3.6 Mengkreasikan konsep cinta tanah air/bela negara dalam konteks Negara Kesatuan Republik Indonesia; 4.6 Mengorganisasikan kegiatan lingkungan yang mencerminkan konsep cinta tanah air dalam konteks kehidupan sehari-hari.

Secara tidak langsung melalui tulisan yang dijadikan sebagai sumber belajar (bahan ajar) ini guru juga bisa memberikan pendidikan karakter pada peserta didik. Pendidikan karakter adalah pendidikan yang menanamkan dan mengembangkan karakter-karakter luhur kepada anak didik, sehingga mereka memiliki karakter luhur itu, menerapkan dan mempraktekkan dalam kehidupannya (Wibowo, 2012: 34).

Pada era covid saat ini banyak pelajaran berharga yang bisa kita ambil, misalnya bagaimana kepedulian kita pada masyarakat, bagaimana kesadaran kita untuk disiplin mematuhi aturan untuk mencegah penyebaran covid 19. Protokol kesehatan untuk mencegah penyebaran covid, seperti selalu memakai masker saat keluar rumah, rajin mencuci tangan dengan memakai sabun, menjaga jarak, menghindari keramaian, tetap tinggal di rumah jika tidak ada sesuatu yang mendesak hindari keluar rumah. Apakah hal tersebut sudah diperhatikan dan dilaksanakan oleh para masyarakat termasuk peserta didik? Kedisiplinan dalam mematuhi aturan ini adalah salah satu karakter yang perlu ditanamkan pada peserta didik di sekolah. Salah satu cara untuk memberikan pemahaman tentang itu bisa melalui tulisan dalam bentuk artikel, 
Menulis artikel bagi guru/ dosen merupakan suatu kebutuhan. Dengan menulis artikel yang dimuat di media massa/ prosiding/ jurnal maka akan dapat menambah angka kredit yang bisa digunakan untuk naik jabatan fungsional. Di samping itu, dengan menulis artikel guru akan semakin terlatih dalam memecahkan masalah-masalah sosial yang dihadapi dalam kehidupan sehari-hari. Namun fakta menunjukkan, bahwa kemampuan guru untuk menulis (artikel) masih sangat rendah. Berdasarkan wawancara awal melalui WA yang dilakukan pada ketua MGMP PPKn kota Surabaya, Ibu Binti mengatakan bahwa kemauan guru dalam menulis masih rendah karena factor usia sehingga agak malas jika diminta untuk menulis artikel. Selain itu kemampuan guru dalam menulis artikel masih dalam kategori rendah, kira-kira hanya $20 \%$ yang mau menulis. Di samping itu, berdasarkan komunikasi melalui WA pada beberapa guru PPKn SMP di kota Surabaya, mengatakan hal yang sama seprti Ibu Binti. Alasan guru jarang menulis artikel adalah karena faktor usia, kemampuan untuk menulis artikel rendah dan kesibukan guru dalam hal administratif.

Berdasarkan atas fakta tersebut di atas maka PKM ini diarahkan pada upaya meningkatkan kemampuan guru dalam menulis artikel tentang covid 19 dalam rangka pendidikan karakter pada peserta didik SMP kota Surabaya. Kemampuan dalam hal menulis karya ilmiah ini tidak tidak datang dengan sendirianya tetapi perlu ada usaha misalnya dengan mengikuti kegiatan menulis karya ilmiah. Pengertian artikel menurut Kamus Besar Bahasa Indonesia (KBBI) adalah suatu karya tulis yang dibuat secara lengkap, seperti esai pada majalah atau laporan surat kabar. Sedangkan menurut beberapa ahli seperti Rillan E. Wolseley, artikel adalah karangan tertulis yang panjangnya tidak dapat ditentukan, dimana tujuannya untuk menyampaikan gagasan maupun fakta dengan maksud meyakinkan, mendidik, ataupun menghibur. Artikel ada artikel ilmiah dan artikel opini. Artikel opini adalah tulisan lepas yang berisi opini seseorang yang mengupas tuntas suatu masalah tertentu yang sifatnya aktual atau konroversi dengan tujuan untuk memberi tahu (informatif), memengaruhi dan meyakinkan atau juga bisa menghibur bagi pembacanya (bersifat recreative) (Kuncoro, 2009). Artikel opini biasanya menekankan pada pendapat pribadi penulis yang memperkuat argumen logis dan pemikiran kritis terhadap suatu masalah aktual (Komaidi, 2007). Opini tidak harus selalu identik dengan bahasa yang kaku. Bahasa yang populer, lincah dan entertaining, dengan anekdot-anekdot yang sesuai kadang membuat tulisan tidak membosankan.

Artikel ilmiah merupakan artikel berjenis deskriptif yang menjelaskan topik-topik secara lengkap dan detail. Artikel ilmiah biasa diterbitkan di sebuah jurnal ilmiah yang tersusun secara sistematis, sesuai fakta, dan masuk akal atau rasional. Mulai dari contoh artikel di koran, contoh artikel ilmiah pendidikan, artikel ilmiah pendidikan, artikel ilmiah kesehatan dan lain-lain. (https://www.mypurohith.com/contoh-artikel-ilmiah). Menurut Asfihan (2020), ada 4 hal yang perlu diperhatikan dalam menulis artikel ilmiah, yaitu (1) Ukuran hasil pemikiran pada suatu objek investigasi, yang dapat berupa hasil penelitian atau gagasan analisis kritis; (2) Dimensi bahasa yang ditulis sebagai alat menyajikan hasil pemikiran penulis dalam bentuk kesatuan makna dan spidol eksplisit untuk hubungan kesatuan makna; (3) Dimensi sistematis dibuat sebagai ciri pembeda antara bentuk tertulis dari artikel dan bentuk tertulis lainnya; (4) Ukuran kaidah, font yang harus diikuti adalah universal (umum) atau lingkungan. Fungsi artikel adalah sebagai rujukan, untuk meningkatkan wawasan dan menyebarluaskan ilmu pengetahuan (Asfihan, 2020). Karena itu, kemampuan guru dalam menulis artikel ini sangat penting dalam rangka meningkatkan wawasan dan menyebarluaskan ilmu pengetahuan pada peserta didik pada khususnya, dan masyarakat pada umumnya.

Coronavirus merupakan keluarga besar virus yang menyebabkan penyakit pada manusia dan hewan. Pada manusia biasanya menyebabkan penyakit infeksi saluran pernapasan, mulai flu biasa hingga penyakit yang serius seperti Middle East Respiratory Syndrome (MERS) dan Sindrom Pernafasan Akut Berat/ Severe Acute Respiratory Syndrome (SARS). Coronavirus jenis baru yang ditemukan pada manusia sejak kejadian luar biasa muncul di Wuhan Cina, pada Desember 2019, kemudian diberi nama Severe Acute Respiratory Syndrome Coronavirus 2 (SARS-COV2), dan menyebabkan penyakit Coronavirus Disease-2019 (COVID-19).

Pada 11 Maret 2020 lalu, World Health Organization (WHO) sudah mengumumkan status pandemi global untuk penyakit virus corona 2019 atau yang juga disebut corona virus disease 2019 (COVID-19). Dalam istilah kesehatan, pandemi berarti terjadinya wabah suatu penyakit yang menyerang banyak korban, serempak di berbagai negara. Sementara dalam kasus COVID-19, 
badan kesehatan dunia WHO menetapkan penyakit ini sebagai pandemi karena seluruh warga dunia Indonesia sebagai salah satu Negara yang terdampak sampai dengan saat ini.

Dalam rangka mencegah penularan covid 19 ini perlu ada upaya edukasi yang bisa dilakukan oleh guru di sekolah pada anak didiknya. Salah satu bentuk edukasi bisa dilakukan dengan menulis artikel ilmiah yang terkait dengan Covid 19. Penyakit covid 19 sampai saat ini belum ada obatnya karena itu untuk memutus mata rantai penyebaran covid 19 ini harus mematuhi cara-cara pencegahan penularan seperti yang telah disebutka di atas. Kesadaran untuk mentaati aturan ini adalah salah satu hal yang sangat penting untuk ditanamkan pada peserta didik.

\section{METODE}

Alternatif kerangka pemecahan masalah yang ditawarkan adalah meningkatkan kemampuan menulis artikel tentang Pandemi Covid 19 dalam rangka pendidikan karakter peserta didik pada guru PPKn SMP di Kota Surabaya. Solusi yang ditawarkan untuk menangani permasalahan yang dihadapi guru adalah pertama, kegiatan diskusi dipilih dalam kegiatan ini karena dengan diskusi pemahaman guru dapat lebih dimantapkan melalui pemikiran-pemikiran yang dituangkan melalui diskusi. Kedua, kegiatan workshop dipilih, karena melalui kegiatan ini para guru memiliki kesempatan untuk mencoba dan berlatih dalam artikel tentang Pandemi Covid 19 dalam rangka pendidikan karakter peserta didik. Adapun yang menjadiTarget luaran yang diharapkan setelah kegiatan ini dilaksanakan adalah supaya terjadi peningkatan pengetahuan guru tentang menulis artikel serta tersusunnya tulisan yang merupakan kumpulan artikel opini/ esai yang dihasilkan oleh guru yang dapat dimanfaatkan sebagai sumber belajar (bahan ajar). Pihak-pihak yang terlibat dalam PKM di MGMP PPKn kota Surabaya ini adalah sebagai berikut, Fakultas Ilmu Sosial dan Hukum Unesa (FISH), yang akan memberikan surat tugas untuk melaksanakan program PKM yang merupakan program FISH Unesa. MGMP PPKn jenjang SMP kota Surabaya, yang memberikan ijin untuk dapat dilaksanakan program PKM dari Tim FISH Unesa. Secara lisan telah menyetujuinya. Secara tertulis diwakili oleh ketua MGMP PPKn Kabupaten Magetan dan Tim PKM prodi PPKn, FISH, Unesa, yang terdiri atas: Listyaningsih, S.Pd., M.Pd (Ketua), Dr. Oksiana Jatiningsih, M.Si. (Anggota), Dr. Totok Suyanto, M.Pd. (Anggota), Agus Satmoko, SS., M.Si. (Anggota), dan Iman Pasu Marganda H. Purba, SH., MH. (Anggota).

Tabel 1.1. Metode dan tahapan dalam Pelaksanaan PKM

\begin{tabular}{|c|l|l|l|}
\hline Waktu & \multicolumn{1}{|c|}{ Metode } & \multicolumn{1}{|c|}{ Aktivitas } & \multicolumn{1}{|c|}{ Keterangan } \\
\hline $\begin{array}{c}\text { Pertama } \\
\text { Wari }\end{array}$ & Workshop & $\begin{array}{l}\text { Narasumber memberi materi tentang konsep } \\
\text { artikel } \\
\text { Pengetahuan tentang problematika menulis } \\
\text { artikel }\end{array}$ & $\begin{array}{l}\text { Daring melalui } \\
\text { zoom }\end{array}$ \\
\hline Hari Kedua & Wondiri & $\begin{array}{l}\text { Peserta membuat artikel tentang covid 19 } \\
\text { dalam rangka pendidikan karakter peserta } \\
\text { didik }\end{array}$ & $\begin{array}{l}\text { Di tempat } \\
\text { masing-masing }\end{array}$ \\
\hline
\end{tabular}

\section{HASIL DAN PEMBAHASAN}

Tahap pertama kegiatan adalah koordinasi. Koordinasi pertama dilakukan tim PKM dengan ketua MGMP PPKn SMP kota Surabaya. Dalam berkoordinasi tidak dilaksanakan secara langsung tetapi melalui Whats App karena masih masa pandemi covid 19. Dari hasil koordinasi terkait dengan kegiatan pelatihan juga tidak bisa dilaksanakan dengan tatap muka langsung, kegiatan dilaksanakan secara online melalui zoo/ google meet.

Tim pelaksana kegiatan PKM, juga melaksanakan koordinasi dilakukan pula untuk penyusunan strategi kegiatan, bahan dan kelengakapan pelatihan, instrumen yang diperlukan, dan pengurusan surat izin atau surat tugas pelaksanaan PKM. Berdasarkan koordinasi yang dilakukan, disepakati bahwa kegiatan dilaksanakan 2 kali. Pada hari pertama akan disampaikan pemaparan 
materi oleh Pak Totok Suyanto, Pak Iman Pasu Purba, dan Pak Agus Satmoko. Sebelum kegiatan dilaksnakan tim PKM Menulis Artikel melakukan koordinasi melalui zoom

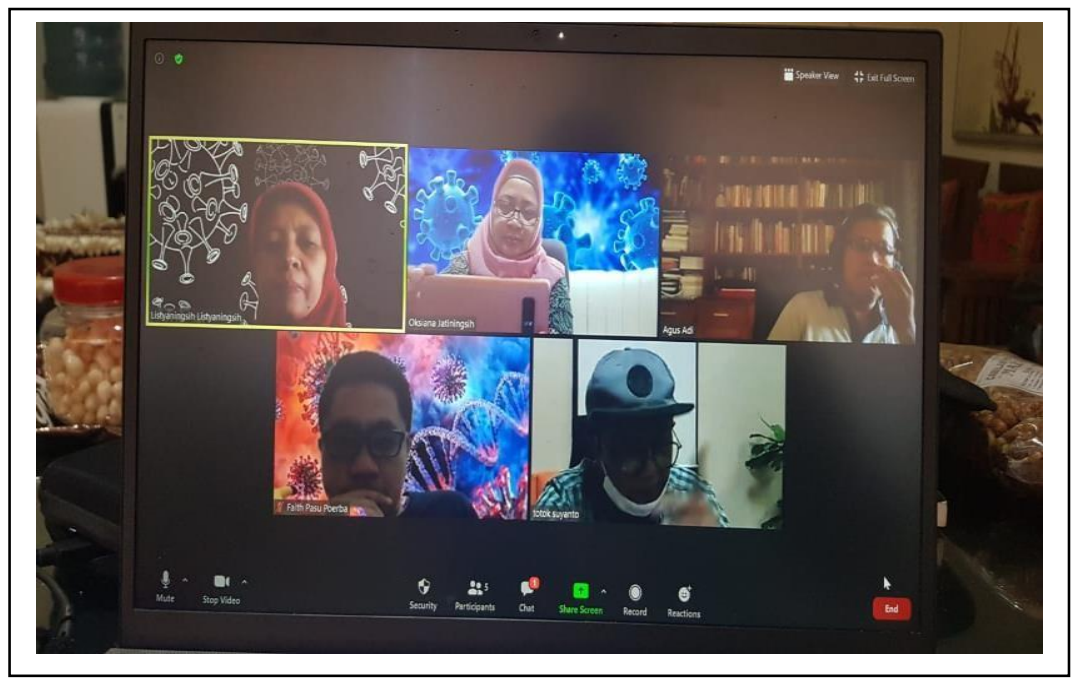

Gambar 1.1 Rapat Koordinasi Internal Tim PKM

Dalam rapat koordinasi ini dilakukan pembagian tugas penyampaian materi tentang menulis artikel, pelatihan menulis, pendampingan dan presentasi. Kegiatan PKM melalui media zoom dilaksanakan dalam 2 tahap dengan jeda waktu 2 minggu setelah pelaksanaan tahap 1. Di samping melalui zoom kegiatan bimbingan juga dilakukan secara daring melalui group whats App. Selang dua minggu kemudian, melalui whats App dilaksanakan kegiatan koordinasi eksternal dengan mitra terkait dengan waktu pelaksanaan kegiata PKM.

Secara operasional kegiatan PKM ini dilaksanakan dalam dua kali pertemuan secara daring, ada jeda dua minggu untuk kegiatan ini. Jeda waktu ini dipergunakan untuk menulia artikel dalam bentuk essay tentang pandemi covid dalam rangka pendidikan karakter bagi peserta didik. Pelaksanaan kegiatan PKM secara keseluruhan sebagai berikut:

Tabel 1.2 Pelaksanaan Kegiatan PKM Menulis Artikel

\begin{tabular}{|l|l|}
\hline \multicolumn{1}{|c|}{ Tanggal } & \multicolumn{1}{c|}{ Kegiatan } \\
\hline 27-28 Juli 2020 & Melakukan koordinasi dengan mitra \\
\hline 10 Agustus 2020 & $\begin{array}{l}\text { Melaksanakan koordinasi secara internal untuk persiapan } \\
\text { pelaksanaan PKM (membuat poster, mengidentifikasi materi dan } \\
\text { lain-lain) }\end{array}$ \\
\hline 11-22 Agustus 2020 & Menyusun materi untuk kegiatan pelatihan \\
\hline 22 Agustus 2020 & Menyusun instrument evaluasi kegiatan \\
\hline 24 Agustus 2020 & Koordinasi persiapan pelaksanaan PKM \\
\hline 25 Agustus 2020 & $\begin{array}{l}\text { Pelaksanaan PKM tahap 1 (penyampaian materi tentang menulis } \\
\text { artikel }\end{array}$ \\
\hline $\begin{array}{l}\text { 26 Agustus - } 10 \\
\text { September 2020 }\end{array}$ & Tugas Mandiri menulis artikel \\
\hline 12 September 2020 & Pelaksanaan PKM tahap 2 (presentasi dan review artikel) \\
\hline 14-21 September 2020 & Membuat laporan Kemajuan \\
\hline 4-10 Oktober & Membuat laporan akhir \\
\hline
\end{tabular}

Pelaksanaan kegiatan pada hari pertama berjalan dengan lancar peserta sangat antusias mengikuti kegiatan, karena kegiatan menulis artikel ini merupakan salah satu masalah yang dihadapi guru. Dengan adanya pelatihan ini, guru mendapat pencerahan kembali tentang menulis artikel dalam hal ini berbentuk esaay yang bisa dimanfaatkan sebagai bahan ajar guru dalam proses pembelajaran. Penyampaian materi pada hari pertama oleh Pak Iman Pasu MH. Purba dengan materi yang berjudul "Mampu Menulis Artikel". Pada materi ini dijelaskan tentang teknik menulis 
artikel utamanya dalam bentuk essay. Langkah-langkah dalam menulis dan tips menulis esaay. Kemudian dilanjutkan oleh Pak Agus Satmoko Adi yang memberikan paparan tentang praktik dalam menulis esaay.

Gambar 1.2 Kegiatan pelatihan pada tnggal 25 Agustus 2020
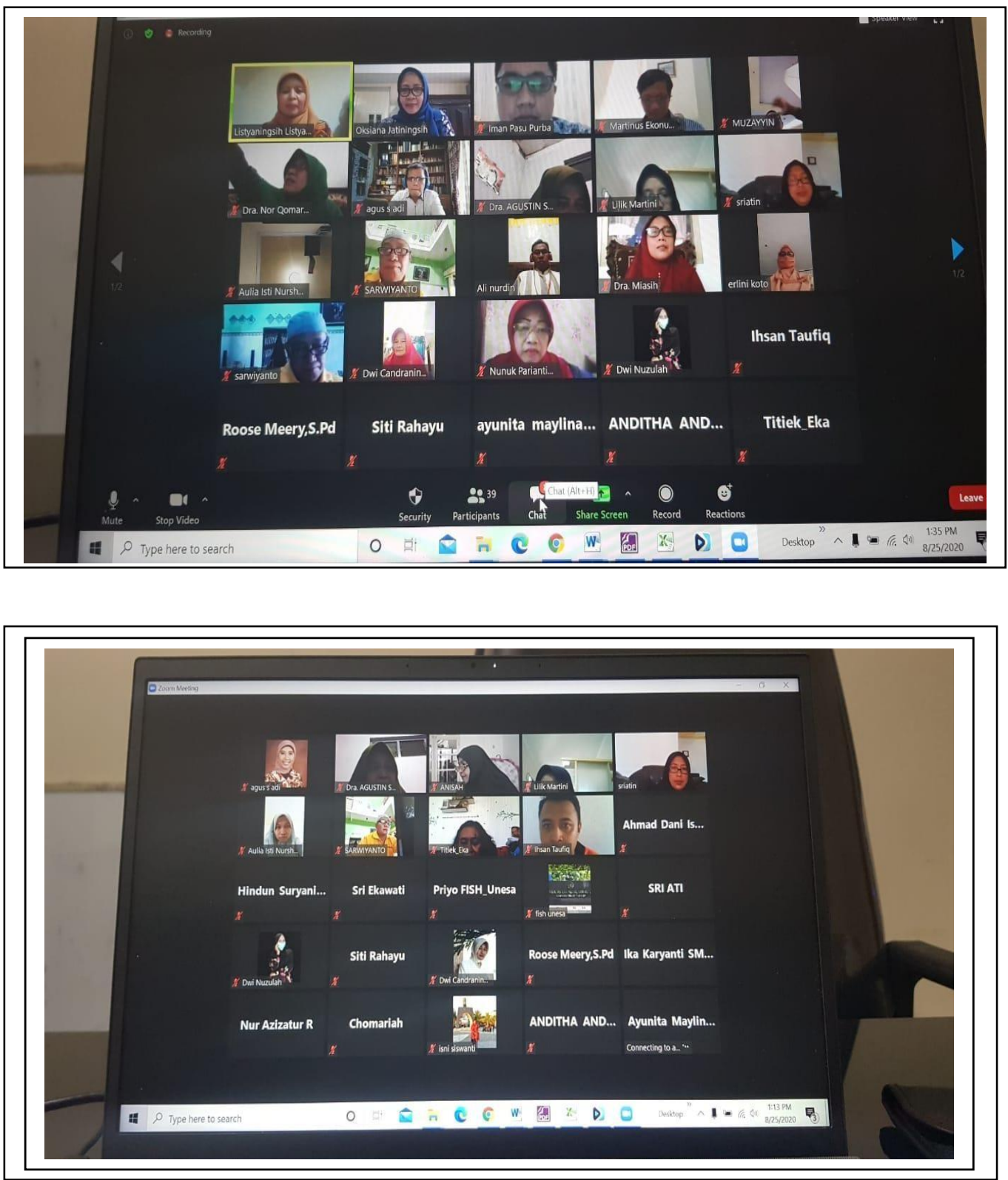
Setelah kegitan tahap 1 ini, kegaiatan selanjutnya tugas mandiri, peserta diminta untuk membuat artikel dalam bentuk essay dengan waktu selama 2 minggu, dari seluruh peserta yang hadir sebanyak 40 peserta yang membuat artikel sebanyak 20 peserta.Pada tanggal 12 September dilaksanakan kegiatan PKM tahap 2, dalam kegiatan ini para peserta diminta untuk mempresentasikan tugas mandiri dalam bentuk artikel.

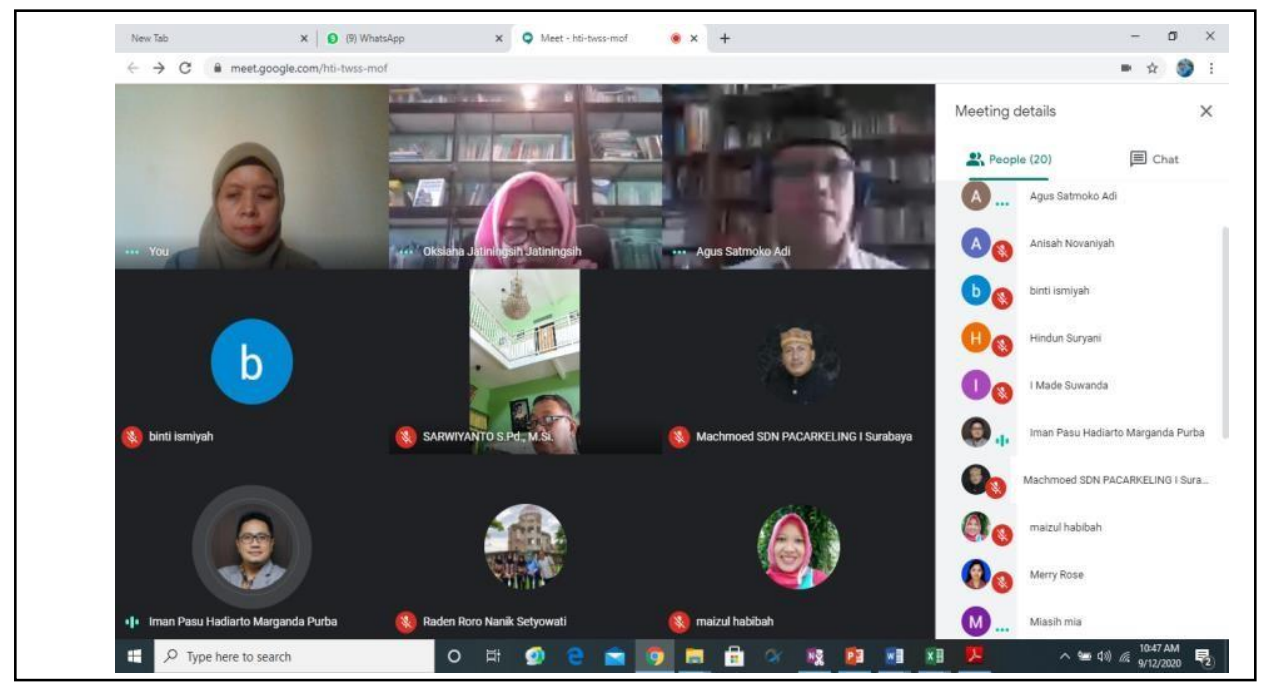

Pengetahuan "menulis artikel" penting dimiliki oleh guru, karena ini adalah sebagai bekal awal agar para guru bisa menulis. Dengan menulis artikel (esai) guru bisa menuangkan gagasan yang bertujuan memberitahu, memengaruhi, meyakinkan pada peserta didik. Di era pandemic seperti yang terjadi sekarang ini banyak sekali berbagai peristiwa yang terjadi di masyarakat yang bisa dijadikan sebagai bahan untuk ditulis. Melalui tulisan artikel dalam bentuk opini (esai) di tengah pandemic covid 19 ini guru dapat memberikan pemahaman bagaimana cara bersikap dan berperilaku yang baik ditengah pandemic Covid 19. Artikel yang dibuat guru ini sekaligus dapat digunakan sebagai sumber belajar (bahan ajar) dalam pembelajaran PPKn.

Di awal kegiatan dilakukan pre test untuk mengetahui kemampuan guru tentang menulis artikel esai. Hasil pre test tampak bahwa dalam kategori sangat baik tidak ada satupun diperoleh peserta. Pada kriteria tidak baik ada 12 peserta sekitar 33\% sedangkan kurang baik 24\%. Dari dua kriteria ini menunjukkan bahwa lebih dari $50 \%$ peserta menunjukkan pengetahuan yang masih kurang

Hasil pre tes tentang pengetahuan dalam hal menulis artikel dapat dicermati pada tabel 1.3 berikut ini:

Tabel 1.3 Hasil Pre Test tentang Pengetahuan Menulis artikel

\begin{tabular}{|c|l|c|c|}
\hline Interval & \multicolumn{1}{|c|}{ Kriteria } & f & $\%$ \\
\hline $9-10$ & Sangat Baik & 0 & \\
\hline $7-8$ & Baik & 7 & 19 \\
\hline $5-6$ & Cukup Baik & 9 & 24 \\
\hline $3-4$ & Kurang Baik & 9 & 24 \\
\hline $1-2$ & Tidak Baik & 12 & 33 \\
\hline Jumlah & & 37 & 100 \\
\hline
\end{tabular}

Berdasarkan data pada tabel 5.2 tentang hasil tes pengetahuan menulis artikel yang dilakukan pada awal kegiatan, dapat dikemukakan bahwa sebagian besar guru (33\%) yang mengikuti kegiatan ini memiliki pengetahuan menulis artikel dalam katagori "tidak baik." Persentase yang sama dalam kategori cukup baik dan kurang baik sebanyak 24\% dan $19 \%$ dalam kategori baik. Berdasarkan hasil ini maka kemampuan guru tentang menulis artikel perlu ditingkatkan. Oleh karena itu, kegiatan pelatihan tentang menulis artikel perlu dilaksanakan. 
Perbandingan jumlah pada masing-masing katagori yang dibuat untuk menggambarkan pengetahuan guru tentang menulis artikel dapat dilihat pada grafik 5.1 berikut ini;

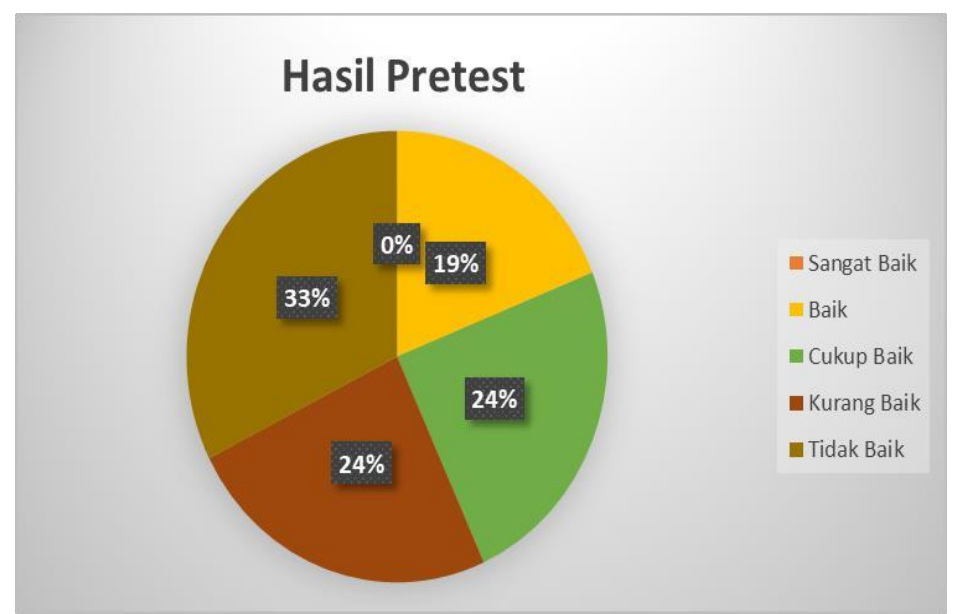

Gambar 1.4 Grafik lingkaran hasil pre test tentang pengetahuan menulis artikel

Pengetahuan guru yang masih dalam katagori tidak baik ini sangat mungkin berkaitan pula dengan kurangnya guru dalam menulis. Aktivitas guru sebagian besar digunakan untuk mempersiapkan dan melaksanakan pembelajaran. Oleh karena itu, pengetahuan guru ini pun perlu ditingkatkan. Dalam kegiatan pelatihan ini diberikan materi oleh tim PKM.

Hasil yang diperoleh guru dalam tes yang dilaksanakan pada akhir kegiatan PKM menunjukkan ada peningkatan persentasi, dimana pada saat pre test tidak ada satupun peserta dalam katagori sangat baik, setelah diberikan materi dan dilaksanakan post test ada peningkatan hasil. Hal ini menunjukkan bahwa peserta memperhatikan dan bisa memahami materi yang telah disampaikan oleh tim PKM. Adapun hasil post test dapat dilihat pada tabel 5.3 di bawah ini:

Tabel 1.4 Hasil Post Test tentang Pengetahuan Menulis Artikel

\begin{tabular}{|c|l|c|c|}
\hline Interval & \multicolumn{1}{|c|}{ Kriteria } & f & $\%$ \\
\hline $9-10$ & Sangat Baik & 4 & 13 \\
\hline $7-8$ & Baik & 5 & 17 \\
\hline $5-6$ & Cukup Baik & 15 & 50 \\
\hline $3-4$ & Kurang Baik & 4 & 13 \\
\hline $1-2$ & Tidak Baik & 2 & 7 \\
\hline Jumlah & & 30 & 100 \\
\hline
\end{tabular}

Berdasarkan tabel di atas, jika disajikan dalam bentuk diagram akan tampak hasilnya sebagai berikut: 


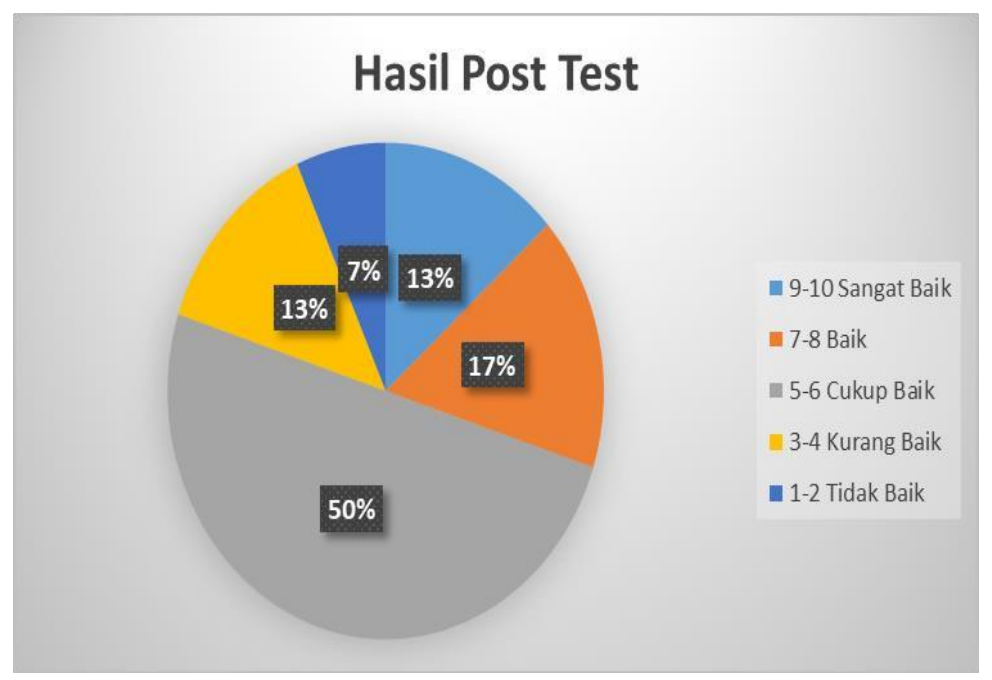

Gambar 1.5 Grafik lingkaran hasil post test tentang pengetahuan menulis artikel

Berdasarkan hasil pre test dan post test tersebut jika kita cermati menunjukkan ada peningkatan pengetahuan peserta pelatihan sebelum dan sesudah kegiatan. Jika sebelum pelatihan ada $33 \%$ peserta dalam kategori tidak baik setelah pelatihan hanya $7 \%$ hanya 2 orang. Ketika pre test tidak ada satupun peserta dalam kategori sangat baik, setelah pelatihan ada $13 \%$ dalam kategori sangat baik. Perbandingan hasil pre test dan post test dapat dilihat pada diagram batang seperti yang ditampilkan di bawah ini:

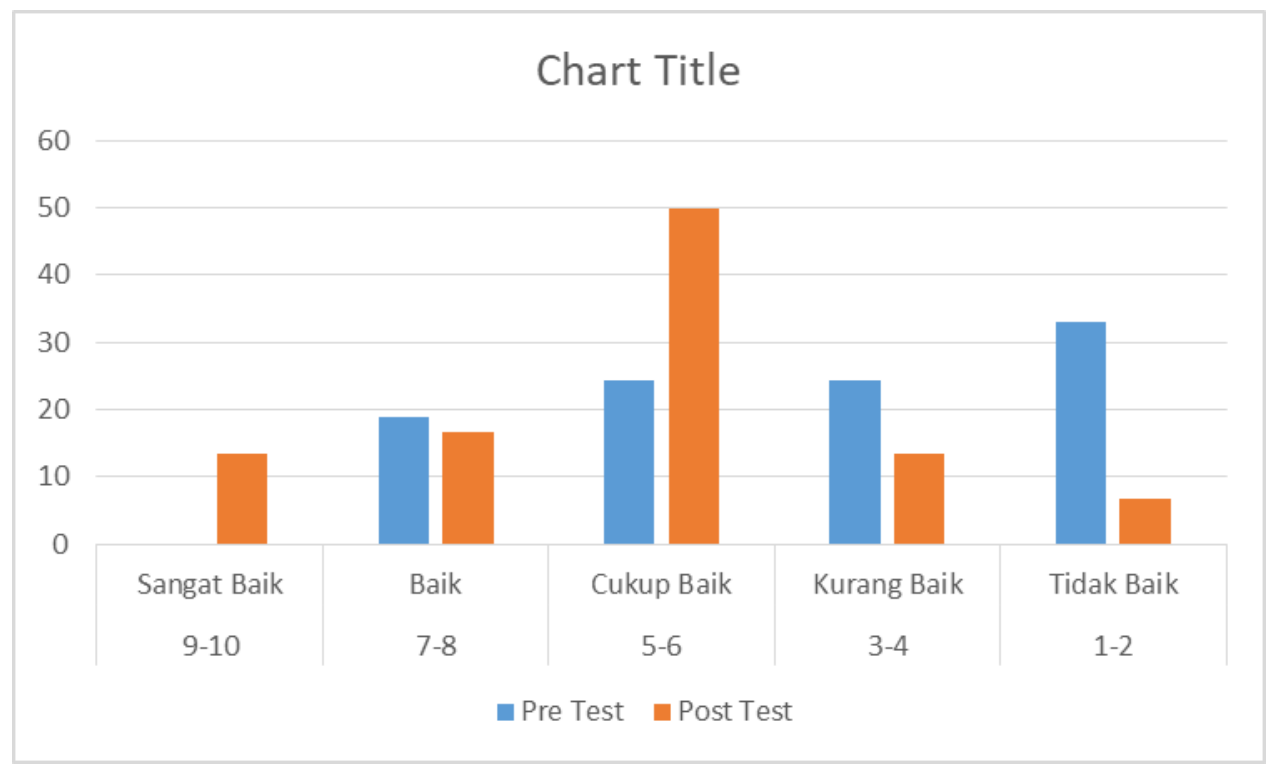

Gambar 1.6 Diagram 1: hasil pre test dan post test kegiatan PKM tentang menulis artikel

Jika diperhatikan diagram di atas tampak adanya perbandingan pre test dan post test tentang pengetahuan guru dalam menulis artikel. Ada peningkatan pengetahuan sebelum dan sesudah pelatihan.

\section{SIMPULAN}

Kegiatan pengabdian ini telah berhasil dalam meningkatkan pengetahuan tentang menulis artikel bagi guru PPKn di kota Surabaya. Ada peningkatan penegetahuan peserta sebelum dan sesudah pelatihan. Hasil pre test dan post test tersebut jika kita cermati menunjukkan ada peningkatan pengetahuan peserta pelatihan sebelum dan sesudah kegiatan. Jika sebelum pelatihan ada $33 \%$ peserta dalam kategori tidak baik setelah pelatihan hanya $7 \%$ hanya 2 orang. Ketika pre 
test tidak ada satupun peserta dalam kategori sangat baik, setelah pelatihan ada $13 \%$ dalam kategori sangat baik.

\section{SARAN}

Kemampuan guru dalam menulis karya ilmiah perlu ditingkatkan.Kegiatan menulis perlu dilatih secara terus menerus sehingga akan terbiasa untuk membuat tulisan.

\section{UCAPAN TERIMA KASIH}

Tim Pengabdian Kepada Masyarakat ini mengucapkan terimakasih kepada Universitas Negeri Surabaya dalam hal ini LPPM UNESA dan Fakultas Ilmu Sosial dan Hukum yang memberi kesempatan dan dana untuk terlaksananya pengabdian kepada masyarakat ini.

\section{DAFTAR PUSTAKA}

Acstylena, Sita. 2018. Pendidikan Karakter Ki Hajar Dewantara. Malang: Madani.

Asfihan, Akbar. Artikel Ilmiah adalah https://adalah.co.id/artikel-ilmiah/ diakses tanggal 26 mei 2020

Hakim, Wildan. 2012. Teknik Menulis Artikel Ilmiah. http://kotaku.pu.go.id:8081/pustaka/files/modul_web/TekniK_Menulis_Artikel_Ilmiah.pdf. Diakses tanggal 26 Mei 2020.

Koesoema, Doni. 2011. Pendidikan Karakter: Strategi Mendidik Anak di Zaman Global. Jakarta: Grasindo.

Lickona, Thomas. 2012. Character Matters: Persoalan Karakter. Jakarta: PT Bumi Aksara. Munthe, Bermawi. 2010. Desain Pembelajaran. Yogyakarta: Pustaka Insan.

Soewandi.Slamet,. A.M. 2005, Pelangi Pendidikan, Universitas Sanata Dharma, Yogyakarta. Suparno, Paul, 1997. Filsafat Konstruktivisme dalam Pendidikan, Penerbit Kanisius, Yogyakarta. Suparno, 2015. Pendidikan karakter di sekolah, Penerbit Kanisius, Yogyakarta.

Ritnaningrum, Ratna. Mengapa Guru Tidak menulis Karya Ilmiah: Perspektif Guru. https://www.researchgate.net/publication/328354043. Diakses tanggal 26 Mei 2020

Sudjana, Nana.2009. Tuntunan Penyusunan karya Ilmiah. Bandung: Sinar Baru Algesindo.

Sujana, dkk. 2019. Pelatihan Penulisan Karya Ilmiah bagi Guru-Guru SMK YZA Bogor https://www.researchgate.net/publication/335462577. Diakses tanggal 26 Mei 2020

Wibowo, Agus. 2012. Pendidikan Karakter. Strategi Membangun karakter Bangsa Berperadaban. Yogyakarta: Pustaka Pelajar.

Yuval Noah Harari, The World After Coronavirus, https://www.ft.com/content/19d90308-685811ea-a3c9-1fe6fedcca75, diakses pada tanggal 31 Agustus 2020

Azyumardi Azra, Nasionalisme, Etnisitas, dan Agama di Indonesia Tantangan Globalisasi,http://www.setneg.go.id. di akses pada 31 Agustus 2020

Benedict Anderson, ImaginedCommunity: Komunitas-Komunitas Terbayang. Terjemahan oleh Omi Intan Naomi. Jogjakarta, 2002, Pustaka Pelajar, Yogyakarta, Hlm. 9

Undang Undang Nomor 4 Tahun 1984 tentang Wabah Penyakit Menular

https://nasional.tempo.co/read/1373830/insentif-tenaga-kesehatan-covid-19-langsung-ke-rekeningpribadi

Keputusan Menteri Kesehatan Republik Indonesia Nomor HK.01.07/MENKES/2020 tentang Pemberian Insentif dan Santunan Kematian Bagi Tenaga Kesehatan Yang Menangani Corona Virus Disease 2019 